\title{
Family and Cultural Capital. The perspective of familiness
}

\section{Familia y Capital Cultural. La perspectiva del familiness}

\author{
Pilar Ortiz García ${ }^{\mathrm{a}^{*}} \cdot$ Ángel Olaz Capitán ${ }^{\mathrm{a}}$ Juan Monreal Martínez ${ }^{\mathrm{a}}$ \\ ${ }^{a}$ Department of Sociology and Social Work, Faculty of Economics and Business, University of Murcia, Murcia
} (Spain)

\section{Article history: \\ Keywords: Family capital \\ Empowerment \\ Culture \\ familiness. \\ JEL codes: \\ M13}

A R T I C L E I N F O

Recibido 06-01-2014

Aceptado 30-10-2014

\begin{abstract}
A B S T R A C T
The influence of the family on a business, its commitment to the company and the values it conveys form a capital capable of influencing the global development of a business. This research analyzes family capital and in particular its cultural components as a resource influencing the direction of the company.

Corporate culture as a guiding philosophy for family business strategy is a key factor in its success. In short, the cultural capital of a family business is a capacity for empowerment. The sharing of values and an agreed definition of the business mission and its beliefs exert an element of cohesion among its human resources giving competitive advantage. The issue is to understand how business performance is influenced.
\end{abstract}

\section{R E S UMEN}

La influencia de la familia en la empresa, su compromiso con el negocio y los valores que transmite, forman un capital capaz de influir en el desarrollo global del proyecto empresarial. En esta investigación se analiza este capital familiar y concretamente los componentes culturales de éste como un recurso para orientar la acción en la empresa. La cultura organizativa, como filosofía orientadora de la estrategia de la empresa familiar, constituye un factor clave de su éxito. En definitiva, el capital cultural de la empresa familiar es una capacidad en términos de empowerment. El hecho de compartir valores, una definición compartida de la misión empresarial y unas creencias que ejerzan como elementos de cohesión entre sus recursos humanos, son un elemento competitivo. De lo que se trata, es de conocer cómo determina los resultados empresariales.

Financed by the Ministry for Science and Innovation through project CSO2010-17761.

* Autor de contacto.

Correoselectrónicos:portizg@um.es,olazcapi@um.es,jmonreal@um.es 


\section{Introduction}

Amongst the various perspectives from which one can tackle the study of family businesses is the cultural perspective. The explanatory capacity of this concept on the behaviours and strategies that develop within a company covers a wide range of issues. The management of human resources, a company's organisational strategy, its relationship with the context or ownership structure and performance are not alien to its business design and definition of the way of doing things ; that is, corporate culture. The analytical usefulness of this concept in the analysis and understanding of the organisational behaviour of a business and how it copes and responds to the environment (Schein, 1998), is now unquestioned; so much so that research on businesses cannot disregard this perspective.

This cultural perspective has been introduced, in its own right, into analysis of business organisations, and family businesses are no exception to this. In this regard, there are numerous studies dealing with the examination of family business from the perspective of their culture (Dyer, 1986; Schein, 1998; Zahra, Hayton and Salvato, 2004, Olson et al 2003), from a comparative perspective comparing them with non-family businesses (Sharma et al., 1997), and how values embodied in these corporations are difficult to imitate (Dierickx and Cool, 1989).

All of these studies have emphasised the uniqueness the family structure imposes on the business and the resulting impact it has on strategic issues such as ownership structure, future planning, that is, inheritance, relations between members based on their family status, management strategy and responsibility or the ever-thorny issue of pay. In all these respects, the importance of family influences on a business can be implicitly or explicitly seen.

This sets out the concept underlying this research, that is, the potential of family influence to contribute as capital to business development. We refer to familiness or family social capital (Pearson, Carr and Shaw 2008; Olson et al., 2003; Cibrian, 2010). The intention is to clarify whether this capital is able to develop the potential of the company or not and notes the competitiveness of family businesses compared to non-family businesses. Therefore, we can ask whether this family capital, embodied by family influence, the congruence between the values of the family and business systems or family involvement with the company, constitute a capacity for action, or can be considered an empowerment factor within the meaning of this concept as a potential trigger for capabilities, in this case, for business.

To arrive at an analysis of the potential of family social capital, we focus on the elements that make up this capital from the cultural perspective, and the theoretical tool used for such an analysis is the FPEC scale (Power, Experience, Culture) by Astrachan, Klien and Smyrnios (2002), upon which the questionnaire used in this research has been based.

The article resulting from this research is structured as follows: the first section develops the theoretical framework, then the methodology used is specified and finally analysis of the research results is provided.

\section{Theoretical framework}

Studies on the topic of corporate culture, which began to be especially abundant from the eighties in the field of business organization (Deal and Kennedy, 1986; Ouchi, 1982; Peters and Waterman, 1982; Schein, 1998; Hall, 1988), have focused on analysis of corporate culture as an internal management factor very important for group cohesion, as well as an element of adaptation to the environment (Thevenet, 1992).

Research on corporate culture as an internal management tool has stressed the importance of culture for the continuity and longevity of organisations (Kaarst-Brown et al. 2004); they have also focused on the role of culture in corporate identity, as a factor that gives a distinctive character to the company and is likely to increase competitiveness and performance (Pümpin and Garcia Echeverria, 1988; Garmendia, 2004). From the perspective of management, they have highlighted the role of culture as a tool used in human resource management. In this sense they have analysed the role of culture as a factor in the integration of members into the corporation. In the same way, when it comes to transforming a group, the first point to be taken into consideration is culture (Infestas, 1991). Corporate culture has played a key role in the strategic approach of businesses, their management of resources and their economic performance (Kotter and Heskett, 1992; Nohria, Joyce and Roberson, 2003).

In most of these studies, theoretical models have been developed that deal with the characterisation of corporate culture (Peters and Waterman, 1982; Deal 
and Kennedy 1986; Pümpin, 1992; Diaz Pividal 1989; De Val Pardo, 1989; Handy, 1978; Cameron and Quinn, 2006; Hofstede, 2001) as benchmarks to try to understand the values and norms which govern organisational strategy and to learn how they influence and sometimes determine the strategy of the company in any given field.

Moreover, the study of culture as an element of adaptation to the business environment also has a long tradition (Freytag and Thurik, 2007; Hofstede, 1980; Ouchi, 1982; Pascale and Athos, 1983). From this point of view, we have studied culture as one of the factors that enables business success in transnational areas.

Of all the different aspects of culture, values are particularly important in the family business. In all these studies, analysis of values such as ethical codes that guide strategy and business conduct has occupied a strategic position. This position is especially significant when considering the family business, in that the extent to which family values are interconnected with the values of the company can determine the success of family businesses in terms of competitiveness and even survival; hence it merits reflection in the theoretical framework of this contribution.

\subsection{Values and business culture}

The analysis of corporate culture already has a sufficiently large body of literature that guides such analysis to the field of values as an essential element of business culture. From this perspective, values constitute the core of the complex concept of corporate culture. Values are part of all definitions of corporate culture. For J.A. Garmendia (1993:145) organisational culture is a system of values transmitted by symbols more or less shared by its participants, historically determined and determining and linked to the environment. Values also occupy a central place in the definition of culture by Hofstede (1980) and H. Ansoff (1985); for these authors, the values of a social group determine their preference for a particular type of strategic behaviour. The norms, values and beliefs guide actions, regulate the behaviour of members of the company, its formal and informal relationships, the way events are perceived, difficulties, conflicts and solutions.

Values are particularly important in the study of family business. The characteristics of family business and the role given to the founder as the source of the values on which it is based and develops has generated a great deal of literature which characterises and defines the company in terms of its cultural orientation (Dyer, 1986; Ward, 1987; Garcia and Lopez, 2001). Family values are also the basis of the culture of the family business and one of its strengths for survival (Aronof, 2004).

However, company values and family values do not always coincide. It is necessary to bear in mind that one or the other were conceived in different, sometimes conflicting, systems (Gallo, 1995). While corporate values are conceived in a context in which the strategy, objectives and professional relationships are the most important elements, family values are formed in a different context; as opposed to objectives and strategy, it is feelings and emotion that guide behaviour. Therefore what is truly interesting to know is to what extent family and company values coincide.

On the other hand, values can be developed in very different ways and not all are likely to impact positively on family and business systems, it depends on each case and the types of behaviour they promote (Cardona, Gallifa and Comillas, 2007). There are values associated with company activity, such as efficiency, cost awareness, professionalism and focus on results that, if they exist in the family, will have a highly positive effect on company progress. Alongside these, there are other associated values which go beyond business profit, that also add to the performance of the relationship between family and business, and, finally, there are relationship values, those that promote respect, communication and teamwork which, if they exist in the family dimension, contribute to business development. These links back to the idea of the importance given to these values in the family but, above all, to their transfer and contribution to the business field. All of this stems from the premise that one and the other space are congruent.

The F-PEC scale proposed and developed by Astrachan, Klien and Smyrnios (2002) allows us to determine the influence of the family on a business along several dimensions: power, experience and culture. This model determines the weight of the family on the business through the development of a scale for each of the dimensions considered. For the culture subscale, these authors test family influence on the company by considering two dimensions: on the one hand, the relationship between family values and those of the company and, on the other, the commitment of the family to the company.

The question we raised in the analysis is as follows: Is the influence of the family on the business positive or negative? It will be positive if 
there is congruence between the values of both systems. Also, this influence will be positive in so far as it contributes to creation of greater family involvement in the business.

\subsection{Family social capital}

One of the hallmarks of family businesses is that their objectives go beyond the purely economic (Olson et al. 2003; Chrisman et al. 2003; Sharma 2004; Hienerth and Kessler, 2006; Pearson et al., 2008; Cibrian, T, 2010). Concern for future generations and maintaining the emotional balance of the family via good management of company resources are important factors in this type of company. There are several theoretical frameworks from which to approach this relationship: the theory of systems (Lansberg, 1983), the theory of resources and capabilities (Habbershon et al., 2003) or that of social capital (Coleman, 1988).

This latter perspective is particularly thoughtprovoking in analysis of the family business in that it helps identify family capital as a resource. The concept of familiness (Olson et al, 2003) refers to the impact of family influence on the strategic processes and performance of the business (Sciascia and Mazzola, 2008 and Miller et al. 2008), from the use of various resources, one being family capital.

Following Hoffman et al. (2006), family capital is a special form of social capital, it is the moral infrastructure that guides relationships between family members. It is a resource for this particular community that makes up the family, in which the values, norms and morally acceptable beliefs are defined and by which members of the family unit are socialized. Therefore, we can treat family and social capital as the capability through which the family business learns to plot out the kind of business it wants to be. Development of this capital may depend, to a large degree, on whether the family influence on the business is positive or negative. Functioning family capital, understands that the driving factors of commitment, communication and teamwork, must be functional for the development of the business. By contrast, dysfunctional family capital has the capacity to contaminate the development of the business (Cibrian, 2010; Le Breton-Miller and Miller, 2009).

There is no doubt that family capital, whether it is functional or dysfunctional, is an important type of social capital that stamps the present and the future of family businesses and makes them different from those companies that are non-family (Cibrian, 2010).

\subsection{The concept of empowerment and family social capital in business}

The term empowerment has various theoretical references, and one of its main inspirations is the concept of social capital. Thus, comparing one term and another underlines the special closeness there is between them (Graf et al., 1999:10), while at the same time pointing to their differences, because while the concept of social capital should be seen primarily as stock and an acquired asset, the term empowerment has to be considered as the capacity, competence and autonomy (Baars et al., 1997:304) to operate in different areas. However, between these two elements there is a close relationship and continuity, because the acquired social capital is that which enables action.

From this perspective, the concept of empowerment is assigned two main functions from the various analyses that have been carried out: to promote, on the one hand, human capabilities and, on the other, the networks associated, by with the through the increase of knowledge and abilities that maximize opportunities for participation in the management at personal and collective level (Beck et al., 2001). Therefore, capacity and competence linked to the concept of empowerment are connected to the resources most appreciated by society such as: skills, experience and ingenuity.

The potential trigger that leads to the concept of empowerment based on the capacity and competence it generates produces effects on three interrelated levels which shape the social system: individual, social and political. This explains why we speak of three types of empowerment, corresponding to the three categories or levels referred to above (Friedman, 1992). Thus, when knowledge, skills and experiences of selfempowerment directly seek self-development, we talk about personal empowerment, when what is at stake is the social aspect through interpersonal relationships, it is called social empowerment and finally, when involved in decision-making, information and resources through knowledge, skills and experiences, it is called political empowerment.

The perspective presented in relation to this concept, characterized by ability, competence and autonomy, allows the decision taken to be meaningful and responsible in that it is based on the 
necessary knowledge, skills and experience, regardless of the type of empowerment involved.

As has been considered, the term empowerment is capable of being applied at different levels, but its use in different fields may also be of service ${ }^{1}$. It is no coincidence in this respect that the European Commission in defining its policy priorities on human and social development makes use of the term, precisely because of the flexibility and potential it possesses and signifies (European Commission: 1996).

In our case, and in the sphere of family social capital, the use of the concept of empowerment is useful, since it leads to enrichment of the analysis of the role of the family in its family business; or expressed in other words, family social capital seen from the concept of empowerment provides knowledge, skills and experiences that guide and manage the company based upon certain values.

Apart from other connotations of family social capital, there are two that need to be taken into account and which are linked to the planes on which corporate culture is expressed: the individual level and the collective level. That is to say, on the one hand, corporate culture refers to specific people, the individual, i.e., the businessman who focuses his philosophy and the behavior of the company according to specific values. But, on the other hand, it also talks about business culture, corporate culture, group culture, family culture, etc.

These two levels (individual and collective) are likewise recognized by the existing literature that deals with the concept of empowerment. However, some cases give more emphasis to the individual aspect involved with said term (Svetlik, 2000:7490); nevertheless, in other cases, both levels are well recognized as elements in empowerment (Berman and Phillips, 2000:329-350), in that ability, competence, autonomy and experiences, referring both to people taken individually and to institutions / organizations and communities / groups / citizens.

Whether referring to family social capital or empowerment, the collective level is equivalent to the macro perspective and the individual level to the micro (Philips and Berman, 2001:129-133). The use of one perspective or another depends on the purpose of the analysis. Furthermore, both perspectives can be combined, if the situation

\footnotetext{
${ }^{1}$ By way of example, in the 1980s the term empowerment was used in France to define political objectives of cities and to evaluate the results so obtained (Belorgey: 1993).
}

requires. Possibly, the combination of both perspectives can enrich the analysis of the reality in question. The existing literature has tended to emphasize one perspective more than the other depending on the orientation of the problem studied. For example, studies in recent years in Europe on Social Quality have prioritized the individual or micro perspective of the empowerment concept, but have not excluded the macro, whereas other analyses from the socio-economic and technological perspective put more emphasis on organizational or macro without here excluding the micro perspective.

\subsection{Corporate culture and empowerment}

From all that has been previously said regarding the concept of empowerment, it becomes clear that this term has two major assets: first, the possibility of generating results through the attainment of competence and capability, and, second, to impact on strategic areas of the social system through participation in social, economic, political and cultural processes (Philips and Berman, 2001:139). That is to say, empowerment has to do with the attainment of skills and abilities that guide human action and human activity. This approach empowers individuals to realize their full human potential, and citizens to participate in processes that affect life in society, whether social, economic or cultural.

If we relate corporate culture with what has just been said about the meaning of empowerment, this leads us to note that both, the individual / employer and the business family, have the possibility of acquiring and providing skills and competences that enable them to have an economic and business impact. Corporate culture expressed in the values that guide the business activity is a result, therefore, of skills, competences and autonomy that the entrepreneurial family has acquired.

In conclusion, the analysis of the behavior of the family business via corporate culture, should consider the values it holds and which reflect the existing social capital expressed by the skills, competences and autonomy that the business family possesses.

\section{Methodological focus}

The study carried out within this article belongs to a wider Research Project in which a number of issues on the Spanish Family Business are analysed. Specifically, this article is based on the model used to measure the influence of the family on the 
business and its impact on the formation of family social capital, we used the F scale - PEC (Power, Experience, Culture) of Astrachan, Klien and Smyrnios $(2002)^{2}$. Specifically, the culture subscale measuring instrument used assessed the extent to which family values are connected with the values of the company and, secondly, the degree of commitment of the family to the company. This model's components are reflected in the item number 9 of the Questionnaire, shown at the end of the article.

The survey was conducted in a total of 500 small and medium sized businesses throughout Spain, by telephone interview with those principally responsible for the company (Director General, Manager, Director of Human Resources and related positions). Fieldwork was carried out between February 28 and March 1, 2011.

To carry out this work we used a sampling frame consisting of a total of 5,113 companies in Spain where the number of workers was between 25 and 249 employees. The sample was divided according to company size, so that 200 surveys were conducted among companies with between 25 and 49 workers, and 300 surveys among enterprises with 50 to 249 workers. Finally, due to the specific aims of this study, the sample concentrated on 282 family businesses.

The sampling error was $\pm 4.25 \%$, considering the number of companies UOE provided in the sampling frame used $(5,113)$ and assuming simple random sampling criteria for the case of maximum uncertainty $[\mathrm{P}$ (probability of the phenomenon $)=\mathrm{q}$ (complementary probability) $=50 \%]$ and a confidence level of $95.5 \%(\mathrm{k}=2)$. The sampling unit selection was made following a systematic random process, through phone calls.

The structured questionnaire consisted of 18 questions relating to the status of fiscal policies, human resources and innovation. The clearance of the data matrix was performed using the programs BARWIN, CODI, MINITAB, EXCEL, SPSS under the coordination of the company IMAES.

This mentioned model allows us to respond to the hypotheses in this study:

${ }^{2}$ Astrachan, J., Klien, S. y Smyrnios, K. (2002): The F-PEC scale of family influence: A proposal for solving the family business definition problem, Family Business Review, Vol. 15 (1): pp. 45 - 58.
- Hypothesis 1. The large degree of family influence in the company might help to establish greater consistency between the values of family and company, which is one of the elements that make up family capital.

Furthermore:

Complementary hypothesis 1. Shared knowledge and information in the family contributes to greater coherence between family values and those pervading in the company.

Complementary hypothesis 2 . Values / culture shape the way things are done. That is, there is a relationship between the existence of codes of conduct shared by family members (consistency and agreement in action) and the values that are transferred to the company.

- Hypothesis 2. There exists a positive relationship between the identity of company and family values and the commitment the family makes to aspects of the business, so family capital will be key when taking decisions affecting the company.

- Hypothesis 3. There is a positive relationship between familiness, family capital and business performance.

\section{Analysis of results}

The companies under study fit the profile of SMEs. $51.1 \%$ have between 25 and 49 workers. As to the business representative interviewed, the majority were male $(92.9 \%)$, with a high educational level $(63.8 \%$ have university degrees) and with extensive experience in management positions (average 18 years), an interesting piece of data when assessing the strength of culture in the family business.

As regards to the view of their own company in relation to its competitors, except in matters dealing with reputation and image (average of 3.8 on a satisfaction scale of 1 to 5), they are not particularly aware of their relative position in terms of profitability (mean 3.5), sales performance (mean 3.4) or financial independence (3.6).

Focusing on the analysis of the culture subscale of the model, the exploitation of the results of the question that addresses this issue can be seen in Figure 1. The response from those surveyed about the connection between family values and the company indicates that the ratio is high (the degree of agreement is at an average of 4.5 on a rating scale of 1 to 5 . However, it is not the highest value amongst the items that comprise this subscale. As 
Figure 1

Median values of the culture subscale.

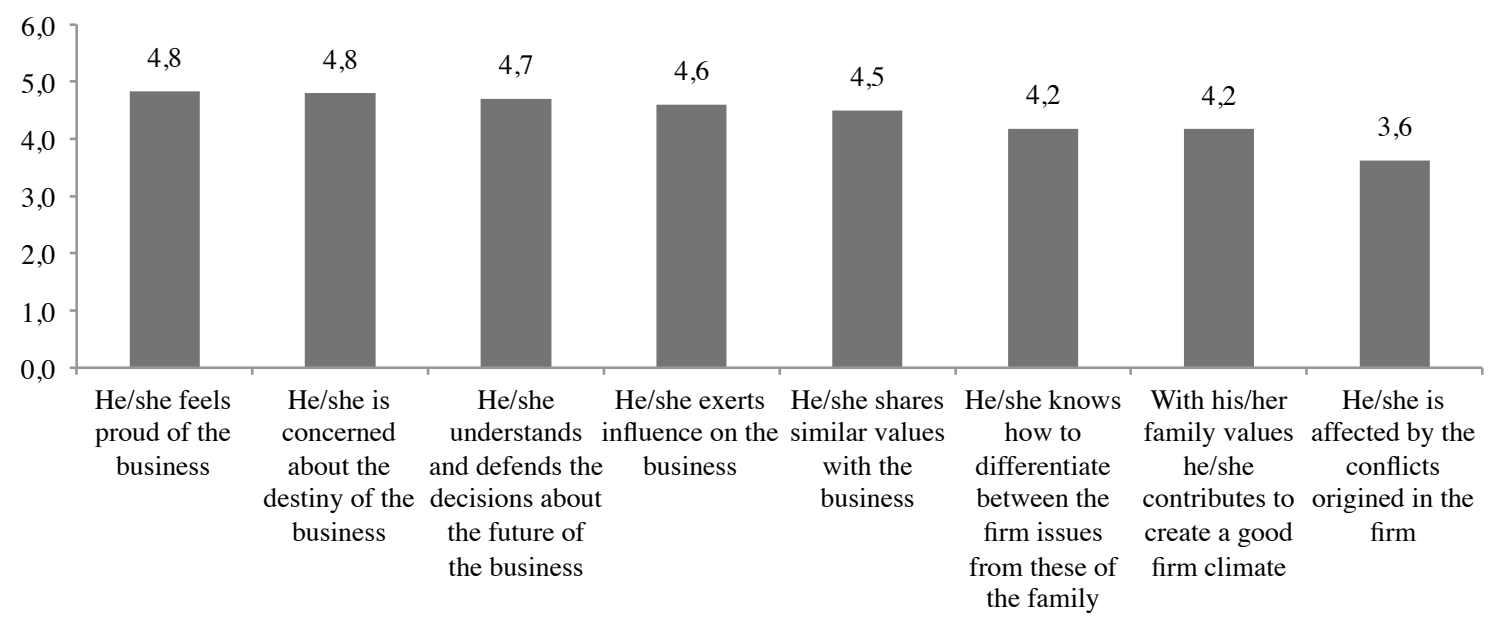

shown in Figure 1, the highest average response of those questioned were the ratings for pride in the business and concern about the future (in both cases the average is 4.8 ).

The importance employers give to decisions on the future of the company and the influence of the family on it are also highly valued (4.7 and 4.6 respective average rating).

From the descriptive analysis of these responses, we are in a position to state that the influence of a family on the business, through values or culture, that is, what the literature on the subject calls familiness (Olson et al., 2002: 452), is important among those surveyed.

The next step is to verify through the data how this influence operates and what consequences it has on the strategic processes and performance of the company, that is, the impact of family capital on the business (Sciascia and Mazzola, 2008 and Miller et al., 2008). This supposes confirmation of the working hypotheses.

Regarding the first of the questions, the hypothesis it intends to contrast (hypothesis 1) is whether the influence of the family on the business contributes to ensuring that family values are close to those of the company (Table 1).

The data confirms that the opinion of businessmen establishes this relationship; $93.8 \%$ of respondents totally agree that the family contributes to the criteria and priorities being in line with prevailing values. This forms an essential part of the existing family capital.

\section{Table 1}

The influence of the family and shared values in the family business (Scale 1-5*) $(\%)^{* *}$.

\section{The owning family share values similar to} the business

\begin{tabular}{llllllll} 
& & 1 & 2 & 3 & 4 & 5 & Total \\
\hline $\begin{array}{l}\text { The } \\
\text { owning }\end{array}$ & 1 & 75.0 & & & & .6 & 1.5 \\
family & 3 & & 60.0 & & 6.7 & .6 & 3.0 \\
$\begin{array}{l}\text { has } \\
\text { influence }\end{array}$ & 4 & & 40.0 & 43.5 & 6.7 & 1.7 & 7.0 \\
$\begin{array}{l}\text { on the } \\
\text { business }\end{array}$ & 5 & 25.0 & & 4.3 & 48.3 & 3.4 & 13.3 \\
\hline Total & & 100.0 & 100.0 & 100.0 & 100.0 & 100.0 & 100.0 \\
\hline
\end{tabular}

* $1=$ Total disagreement and $5=$ Total agreement

**Asymptotic significance test - Pearson's chi-squared test: 0.000 .

A further step in reinforcement of the existence of family capital will be to ascertain that values guide the actions of the family in the company; this poses another way of specifying the influence of family values (Table 2).

Thus is emphasised the possible relationship between the existence of codes of conduct shared by family members (consistency in action and agreement on it) with the fact that there is cohesion of values with the business. The values / culture shape the way things are done (complementary hypothesis 1).

This confirms that family capital is a strategic resource guiding action. Therefore, not only the vision of the company is specified, but also its mission $(42.9 \%$ of businessmen demonstrate they strongly agree with this relationship). 
Table 2

Shared values and codes of conduct in the family business (Scale $\left.1-5^{*}\right)(\%)^{* *}$. The owning family share values similar
to the business

\begin{tabular}{llllll}
1 & 2 & 3 & 4 & 5 & Total \\
\hline
\end{tabular}

\begin{tabular}{llllllll}
$\begin{array}{l}\text { Importance } \\
\text { of codes of }\end{array}$ & 1 & 25.0 & & 18.2 & 8.9 & 4.9 & 7,2 \\
$\begin{array}{l}\text { conduct } \\
\text { shared by }\end{array}$ & 2 & 25.0 & 60.0 & 13.6 & 5.4 & 6.7 & 8,4 \\
family & 3 & 25.0 & 20.0 & 22.7 & 32.1 & 17.2 & 21,2 \\
members & 4 & 25.0 & & 18.2 & 41.1 & 28.2 & 29,6 \\
& 5 & 20.0 & 27.3 & 12.5 & 42.9 & 33,6 & \\
& 100 & 100.0 & 100.0 & 100.0 & 100.0 & 100.0 \\
\hline Total & *1=Total disagreement and 5=Total agreement \\
**Asymptotic significance test - Pearson's chi-squared test: 0.000.
\end{tabular}

To complement the specification of the results of family influence in the construction of a cultural corpus in the company, it is advisable to consider the ratio of shared knowledge and information in the family and the fact that there is greater coherence between family values transferred to the business (Table 3) (supplementary hypothesis 2).

In this regard, $52.4 \%$ of employers surveyed expressed the highest level of agreement on the relationship between both factors.

Table 3

Shared values and communication among members of the family business (Scale 1-5*) (\%)**.

\begin{tabular}{|c|c|c|c|c|c|c|c|}
\hline & & \multicolumn{5}{|c|}{$\begin{array}{l}\text { The owning family share values } \\
\text { similar to the business }\end{array}$} & \multirow[b]{2}{*}{ Total } \\
\hline & & 1 & 2 & 3 & 4 & 5 & \\
\hline \multirow{5}{*}{$\begin{array}{l}\text { Importance } \\
\text { of: sharing } \\
\text { information } \\
\text { and } \\
\text { knowledge } \\
\text { among } \\
\text { family } \\
\text { members }\end{array}$} & 1 & 25.0 & & 9.1 & 5.5 & 4.1 & 5.1 \\
\hline & 2 & & 25.0 & 4.5 & & 2.9 & 2.7 \\
\hline & 3 & 25.0 & 50.0 & 18.2 & 23.6 & 12.9 & 16.5 \\
\hline & 4 & 25.0 & & 9.1 & 49.1 & 27.6 & 30.2 \\
\hline & 5 & 25.0 & 25.0 & 59.1 & 21.8 & 52.4 & 45.5 \\
\hline \multicolumn{2}{|c|}{ Total } & 100.0 & 100.0 & 100.0 & 100.0 & 100.0 & 100.0 \\
\hline
\end{tabular}

With the establishment of these early relationships we are in a position:

- To find that the influence of the family (familiness) as a prerequisite for the formation of a family social capital is positively related to the configuration of values; in particular, the greater the influence of the family, the greater symbiosis between family values and business. The first hypothesis is therefore confirmed.
- To state that values and behaviour are closely related. The fact of sharing similar family and business values guides behaviour, since more common codes exist. Therefore, values and culture are revealed as guiding the work of members in the family business. This is important since culture is shaped as a capacity (empowerment) for strategic action in the company.

- To note that there is a highly positive relationship between communication and symbiosis between family and business values. That is, shared knowledge and information in the family contributes to greater coherence between the values that are transferred to the company. And furthermore, strongly constructed values allow for better sharing of knowledge and information.

Determining the degree of family involvement with the company is the second major objective of the culture subscale F-PEC. All aspects that cover this subscale contribute to specifying that responsibility. However, there are some aspects such as pride in the company, concern for its future and the degree of understanding and justification of decisions affecting the future of business, which particularly identify family commitment with the business. As shown in Figure 1, these items get the highest average rating from those surveyed, suggesting that good raw material exists for the formation of family capital that impacts on business performance. However, the cultural subscale presumes a relationship between shared familybusiness values and the commitment of the family to the business, or what is the same, the greater the cohesion between values, the greater the commitment. This leads to another hypothesis of this research (hypothesis 2). In the family businesses analysed, the relationship of these variables yields the results shown in Tables 4, 5 and 6.

\section{Table 4}

Shared values and satisfaction with the family business $\left(\right.$ Scale $\left.1-5^{*}\right)(\%)^{* *}$.

\section{The owning family is proud of the business}

\begin{tabular}{llllll} 
& & 3 & 4 & 5 & Total \\
\hline $\begin{array}{l}\text { The owning } \\
\text { family share } \\
\text { values similar to } \\
\text { the business }\end{array}$ & 2 & 30.0 & 3.8 & & 1.7 \\
& 3 & 40.0 & 19.2 & 6.0 & 8.6 \\
& 4 & 20.0 & 65.4 & 17.7 & 22.4 \\
& 5 & 10.0 & 11.5 & 74.6 & 66.0 \\
\hline Total & 100.0 & 100.0 & 100.0 & 100.0 \\
\hline *1=Total disagreement and 5=Total agreement \\
$* *$ Asymptotic significance test - Pearson's chi-squared test: 0.000.
\end{tabular}


The relationship between shared values and pride in the business is significant. $74.6 \%$ of employers expressed they strongly agree with this statement (Table 4).

Similarly, it is clear that for the respondents there exists a relationship between shared values and their involvement in the future of the company. When $73.4 \%$ of respondents position themselves with strongly agree on the relationship between family influence and the symbiosis between family and business values (Table 5), a significant causal relationship can be established.

Table 5

Shared values and concern for the future of the company (Scale $\left.1-5^{*}\right)(\%)^{* *}$.

The owning family is concerned about the future of the business

\begin{tabular}{|c|c|c|c|c|c|c|c|}
\hline & & 1 & 2 & 3 & 4 & 5 & Total \\
\hline \multirow{5}{*}{$\begin{array}{l}\text { The } \\
\text { owning } \\
\text { family } \\
\text { share } \\
\text { values } \\
\text { similar } \\
\text { to the } \\
\text { business }\end{array}$} & 1 & 50.0 & & & & 1.3 & 1,5 \\
\hline & 2 & & 33.3 & 22.2 & 5.6 & & 1,5 \\
\hline & 3 & & 66.7 & 33.3 & 27.8 & 5.5 & 8,6 \\
\hline & 4 & & & 11.1 & 66.7 & 19.8 & 22,3 \\
\hline & 5 & 50.0 & & 33.3 & & 73.4 & 66,2 \\
\hline Total & & 100.0 & 100.0 & 100.0 & 100.0 & 100.0 & 100.0 \\
\hline
\end{tabular}

$* 1=$ Total disagreement and $5=$ Total agreement

**Asymptotic significance test - Pearson's chi-squared test: 0.000 .

As in the previous relationship, $74.6 \%$ of respondents position themselves with strongly agree on the relationship between the justification of business decisions and the symbiosis between family and business values (Table 6), which also indicates important causality.

As a result of this analysis, we can conclude the close relationship between the identity of values in the business and the family, and the family's commitment on issues such as decisions affecting the future of the company and pride in it.

That is to say, when family values are similar to those of the business, the ability to take decisions about the future of the business is easier. It also benefits the level of commitment to the future of the business; however on this last point the results are not conclusive.

Possibly the very wording of the question $\mathrm{He} / \mathrm{she}$ understands and justifies the decisions affecting the future of the company has undermined the results, as it has two affirmatives, that is, understanding does not necessarily imply justification of decisions taken.
Table 6

Shared values and involvement in decisions in the family business (Scale 1-5*) $(\%)^{* *}$.

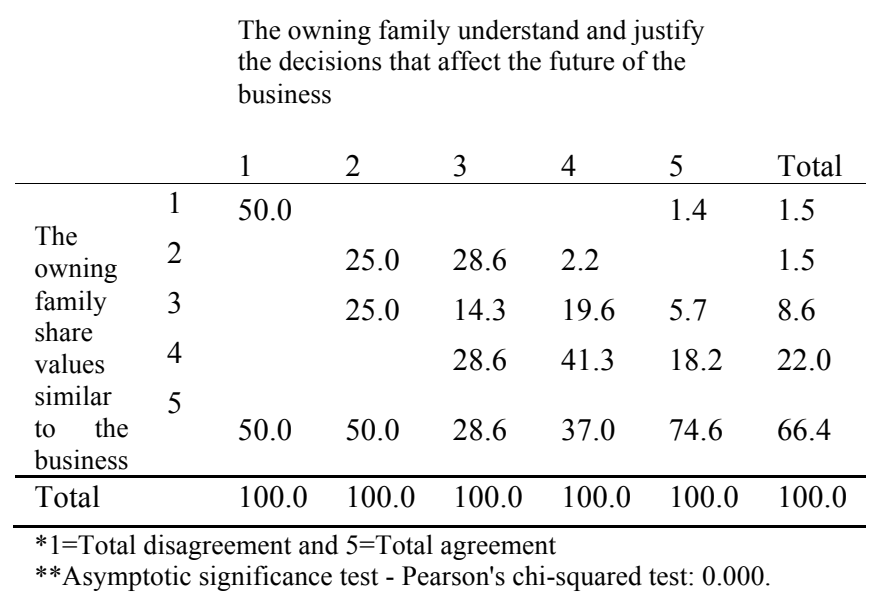

Given these positive relationships between values and commitment, it is possible to verify the third hypothesis, the one that links familiness and family capital with business performance.

The aspects that are identified with familiness in the cultural subscale are those relating to the family influence on the business and the structure of the culture in terms of values, coupled with family commitment to the business, that is, when joined together, family capital.

The theory in this regard (Astrachan et al., 2002) indicates that business performance in terms of profits, profitability or output is a function of familiness (family strength, business structure and culture and family experience) and family capital (the sum of social, human and financial capital).

When we pose as interrogatives the questions seeking to confirm hypothesis 3, the following questions result: When the family is more influential in the business, does this increase its profitability? (Table 7).

Is there an influence on performance when there is a closer relationship between family values and those of the company, in essence, a base of shared cultural or moral infrastructure? (Table 8). Does pride and satisfaction in the business contribute to improving performance? (Table 9). Is concern for the future of the business linked with performance? (Table 10). Does the family's agreement with and commitment to the decisions adopted by the business contribute to better perception of performance? (Table 11).

To facilitate understanding of the proposed analysis, we have constructed a variable that groups together data related to the profitability of the 
business $^{3}$. Re the first question, the results are inconclusive.

The profitability of the company or, more precisely, how this is perceived by its owner, does not necessarily derive from the influence of the family, above all when for various reasons, such as when there are non-family professionals and technicians or particular circumstances, any of which may be responsible for the performance.

This was the perception of $50 \%$ of respondents and only $23.2 \%$ strongly agreed with this causal relationship (Table 7).

\section{Table 7}

Family influence and profitability in the family business (Scale 1-5*) (in \%)**.

The owning family has influence on the business

\begin{tabular}{|c|c|c|c|c|c|c|c|}
\hline & & 1 & 2 & 3 & 4 & 5 & Total \\
\hline $\begin{array}{l}\text { The owning } \\
\text { family }\end{array}$ & 1 & & & & & 3.0 & 2,2 \\
\hline perceives & 2 & & 12.5 & 5.9 & 9.1 & 7.7 & 7,8 \\
\hline $\begin{array}{l}\text { more } \\
\text { profitability/ }\end{array}$ & 3 & & 25.0 & 52.9 & 48.5 & 30.4 & 33,9 \\
\hline $\begin{array}{l}\text { better sales } \\
\text { performance }\end{array}$ & 4 & 50.0 & 37.5 & 35.3 & 30.3 & 35.7 & 35,2 \\
\hline $\begin{array}{l}\text { / greater } \\
\text { financial }\end{array}$ & & & & & & & \\
\hline independence & 5 & 50.0 & 25.0 & 5.9 & 12.1 & 23.2 & 20,9 \\
\hline Total & & 100.0 & 100.0 & 100.0 & 100.0 & 100.0 & 100.0 \\
\hline
\end{tabular}

Table 8

Shared family/business values and profitability in the family business (Scale 1-5*) (\%)**.

\begin{tabular}{|c|c|c|c|c|c|c|c|}
\hline & & \multicolumn{4}{|c|}{$\begin{array}{l}\text { The owning family share values } \\
\text { similar to those of the business }\end{array}$} & \multirow[b]{2}{*}{5} & \multirow[b]{2}{*}{ Total } \\
\hline & & 1 & 2 & 3 & 4 & & \\
\hline \multirow{5}{*}{$\begin{array}{l}\text { The owning } \\
\text { family perceives } \\
\text { more } \\
\text { profitability / } \\
\text { better sales } \\
\text { performance / } \\
\text { greater financial } \\
\text { independence }\end{array}$} & 1 & & & 5.0 & & 2.9 & 2.3 \\
\hline & 2 & & 25.0 & 5.0 & 11.1 & 7.1 & 8.1 \\
\hline & 3 & & 25.0 & 50.0 & 42.6 & 30.0 & 34.2 \\
\hline & 4 & 75.0 & 25.0 & 25.0 & 33.3 & 35.7 & 34.7 \\
\hline & 5 & 25.0 & 25.0 & 15.0 & 13.0 & 24.3 & 20.7 \\
\hline Total & & 100.0 & 100.0 & 100.0 & 100.0 & 100.0 & 100.0 \\
\hline
\end{tabular}

Nor does analysis of the data show the existence of a positive relationship between the identification

\footnotetext{
${ }^{3}$ Question 2 of the questionnaire recoded into a variable that covers options 1, 2 and 3 (profitability, financial independence and sales performance).
}

of values within the family and the business and its results in terms of profitability, sales and financial independence (Table 8 ). Only $24.3 \%$ of employers strongly agreed with this list of variables.

The results listed in Tables 9, 10 and 11 are quite conclusive in a negative sense, that is, the perception of entrepreneurs concerning business performance is weakly determined by variables related to pride in the business or family concerns about the future or involvement in decision making. In this sense, although the family is shown to be a system whose balance is important for the survival and good atmosphere of the business, it is not a determinant of its profitability. This question may be determined as much by strategic factors related to management, such as atmosphere, as by the competitive environment.

\section{Table 9}

Satisfaction with the business and profitability in the family business (Scale 1-5*) (en \%)**.

$$
\text { The owning family is proud of the }
$$
business

\begin{tabular}{|c|c|c|c|c|c|}
\hline & & 3 & 4 & 5 & Total \\
\hline $\begin{array}{l}\text { The owning } \\
\text { family perceives }\end{array}$ & 1 & & & 2.6 & 2.2 \\
\hline more & 2 & 11.1 & 24.0 & 5.7 & 7.9 \\
\hline better sales & 3 & 55.6 & 32.0 & 33.0 & 33.8 \\
\hline $\begin{array}{l}\text { performance } \\
\text { greater financial }\end{array}$ & 4 & 22.2 & 32.0 & 36.6 & 35.5 \\
\hline independence & 5 & 11.1 & 12.0 & 22.2 & 20.6 \\
\hline Total & & 100.0 & 100.0 & 100.0 & 100.0 \\
\hline
\end{tabular}

According to the results shown in Table 10, only $21.7 \%$ of respondents are aware of a highly positive relationship between profitability and concern for the future of the company.

\section{Table 10}

Family involvement with the future of the business and profitability in the family business (Scale $1-5 *$ ) (in \%)** The owning family is concerned about the future of the business

\begin{tabular}{|c|c|c|c|c|c|c|c|}
\hline \multirow{3}{*}{$\begin{array}{l}\text { The owning } \\
\text { family }\end{array}$} & & 1 & 2 & 3 & 4 & 5 & Total \\
\hline & 1 & & & & & 2.5 & 2,2 \\
\hline & 2 & & 25.0 & & 11.8 & 7.6 & 7,9 \\
\hline $\begin{array}{l}\text { more } \\
\text { profitability / }\end{array}$ & 3 & & 75.0 & 57.1 & 35.3 & 32.3 & 33,8 \\
\hline $\begin{array}{l}\text { better sales } \\
\text { performance } \\
/ \quad \text { greater }\end{array}$ & 4 & 50.0 & & 28.6 & 41.2 & 35.9 & 35,5 \\
\hline $\begin{array}{l}\text { financial } \\
\text { independence }\end{array}$ & 5 & 50.0 & & 14.3 & 11.8 & 21.7 & 20,6 \\
\hline Total & & 100.0 & $\overline{00.0}$ & 100.0 & 100.0 & 100.0 & 100.0 \\
\hline
\end{tabular}

$* 1=$ Total disagreement and $5=$ Total agreement

**Asymptotic significance test - Pearson's chi-squared test: 0.770 .

As in the previous case, the percentage of respondents $(34.3 \%)$ who establish a close 
relationship between profitability of the business and decision making in it (Table 11) is not high. However, in this case, the causal relation is somewhat narrower than in previous cases.

\section{Table 11}

Family involvement with business decisions and profitability in the family business (Scale $\left.1-5^{*}\right)(\text { in } \%)^{* *}$.

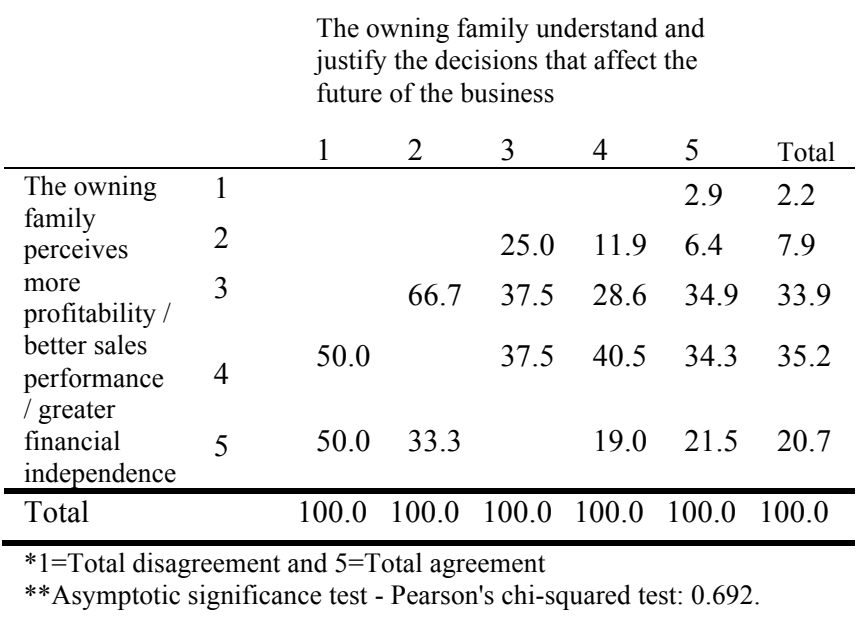

The results of the survey data from the family businesses under study allow the following assertions: the perception of entrepreneurs of the performance of their companies, in terms of profitability, sales and financial independence (relative to competitors) does not show close correlation with the power and influence of the family in the company, which leads to rejection of hypothesis 3 as posed.

Based on the data, it cannot be asserted that business performance, in the terms analysed, depends on the existence of a symbiosis between the values of the family and those of the business. Nor do other aspects, such as pride in the business or the justification of the strategy followed by the business provide factors determining sales or profitability, leading to the conclusion that the elements defining family capital can be contributing factors in achieving results indirectly, that is, by creating a climate in which such results can be attained, but they are not factors determining business performance.

\section{Conclusions}

The study of cultural capital in the context of the family business is an area that, even though it has been covered by many studies, is still worthy of investigation because of the wealth of elements that come together in its modeling, the open interactivity that occurs between its different components and the flexible significance accorded to its various manifestations.

The concept of familiness facilitates the operationalization of the variable culture of family business and allows discovery of the extent to which intangible elements, such as values or the influence of the family, provide a resource or capacity for action in the company. The analysis of family capital in terms of empowerment means consideration of knowledge, skills and experiences that lead to the direction and management of the company according to certain values. Empowerment is the attainment of competence to guide the path, meaning and intensity of activity and their expression through performance in the field of family business.

Family capital, consisting of variables that are part of the family culture is a factor in the performance of the company. As shown from the research hypotheses, the influence of the family correlates positively with the configuration of values. These values guide behaviour and additionally connect to the culture so forming the backbone of the actions of members of the family business.

Similarly, strong correlation is shown between communication and the symbiosis that exists between family and business values. In other words, sharing knowledge and information in the family contributes to greater coherence between the values that are transferred to the company.

Secondly, one can corroborate a close relationship between the identity of company/ family values and the commitment that the family establishes to issues such as decisions affecting the future of the company and pride in it.

In other words, when family and business values are similar, there is greater efficiency in making business decisions, which in principle will result in a more predictable, more assured and possibly more manageable future.

Finally, with regard to possible correlations between familiness and family capital with business performance, the first observations found appear to be less conclusive than might initially have been ventured. It can be argued that the concept of profitability is a term that covers a wide semantic field.

The different meanings that the term has, together with the constraints posed by the attempt to measure what is or is not profitable, not to mention the personal subjectivity with which each individual understands what is effective and efficient, makes it 
difficult to establish a clear and direct correspondence with the concept of social capital. As well as all these aspects, it should not be forgotten that in the search for a precise meaning, provided that the quantitative is tied to the qualitative, methodological difficulties may arise in the description of a virtuous circle with explanatory power.

In any event and admitting the possible constraints and difficulties of integrating and connecting complex elements, it is no less exciting to continue to move forward in the ever unique world of cultural capital in the sphere of family business, to explore new horizons.

\section{References}

Ansoff, H. (1985). La dirección y su actitud ante el entorno. Bilbao: Deusto.

Aronof, C. (2004). Self perpetuation family organization built on values: Necessary condition for long term family business survival. Family Business Review, 17(1), 55-59.

Astrachan, J., Klien, S. and Smyrnios, K. (2002). The F-PEC scale of family influence: A proposal for solving the family business definition problem. Family Business Review, 15(1), 45-58.

Baars, J. et al. (1997). Conclusion: Towards Social Quality in Europe. In Beck W. et al. (Eds.), Social Qualily: A Vision for Europe. The Hague: Kluwer Law International.

Beck, W. et al. (2001). Processes challenging the concept of social quality. In Beck, W. et al. (Eds.): Social Qualily: A Vision for Europe. The Hague: Kluwer Law International.

Belorgey, J.M. (1993). Évaluer les Politiques de la Ville. Paris: Comité d'Évaluation de la Politique de la Ville.

Coleman, J. (1988). Social capital in the creation of human capital. American Journal of Sociology, 93, 95120.

De Val Pardo, I. (1989). Estructura de organización de la empresa pública y la privada. Papeles de Economía Española, 39-40, 116-131.

Dierickx, I. and Cool, K. (1989). Asset Stock Accumulation and Sustainability of Competitive Advantage. Management Science, 35, 1504-1513.

Dyer, W.G. (1986). Cultural change in family firms: Anticipating and managing business and family transitions. San Francisco: Jossey-Bass.

European Comission (1996). Human \& Social Development (HSD). Working paper from the Commision, Part III, EU Policy priorities for HSD, 2, 06/95-11/97 (Brussels, DGV).
Freytag, A. and Thurik, R. (2007). Entrepreneurship and its determinants in a cross country setting. J. Evol. Econ. 17, 117-131.

Friedman, J. (1992). Empowerment. The politics of alternative development. Cambridge: Blackwell.

Gallo, M.A. (1995). Empresa Familiar. Texto y Casos. Madrid: Editorial PRAXIS, S.A.

García, E. and López, L. (2001). A taxonomy of founders based on values: The root of family business heterogeneity. Family Business Review, 14(3), 209-230.

Garmendia, J.A. y Parra, F. (1993). Sociología industrial y de los recursos humanos. Madrid: Taurus.

Garmendia, J.A. (2004). Impacto de la cultura en los resultados de la organización. Revista Española de Investigaciones Sociológicas, 108, 75-96.

Graf, F.W. (1999). Soziales Kapital in der Bürgergesellschaft. Stuttgart: Verlag W. Kohlhammer.

Habbershon, T., Williams, M. and Mcmillan, I. (2003). A unified systems perspective of family firm performance. Journal of Business Venturing, 18, 451-565.

Hall, P.D. (1988). A historical overview of family firms in the United States. Family Business Review, 1(1), 51-68.

Handy, C. 1978). Gods of management: The changing work of organizations. USA: Oxford University Press.

Hienerth, C. \& Kessler, A. (2006). Measuring success in family businesses: The concept of configurational fit. Family Business Review, 19, 115-134.

Hoffman J., Hoelscher M. and Sorenson R. (2006). Achieving sustained competitive advantage: a family capital theory. Family Business Review, 19(2), 135-145.

Hofstede, G. (1980). Culture's consequences: International differences in work-related values. Beverly Hills, CA: Sage Publications.

Hofstede, G. (2001). Culture's Consequences: Comparing Values, Behaviors, Institutions, and Organisations across Nations. Beverly Hills, CA: Sage Publications.

Infestas, A. (1991). Sociología de la Empresa. Salamanca: Amarú.

Kaarst-Brown, M.L., Nicholson, S., Von Dran, G.M. \& Stanton, J.M. (2004). Organizational culture of libraries as a strategic resource. Library Trends, 53(1), 33-53.

Kotter, J.P. and Heskett, J.L. (1992). Corporate Culture and Performance. New York: Free Press.

Lansberg, I. (1983). Managing Human Resources in Family Firms: The Problem of Institutional Overlap. Organizational Dynamics, 12(1), 39-46.

Le Breton-Miller, I. and Miller, D. (2009). Agency vs. Stewardship in public family firms. A social 
embeddedness reconciliation. Entrepreneurship Theory and Practice, 33(6), 1.169-1.191.

Miller, D., Le Breton-Miller, I. and Scholnick, B. (2008). Stewardship vs. Stagnation: An Empirical Comparison of Small Family and Non-Family Businesses. Journal of Management Studies, 45(1), 50-78.

Nohria, N., Joyce, W. and Roberson, B. (2003). What Really Works. Harvard Business Review, 81(7), 42-52.

Olson, P. et al. (2003). Impact of family and business on family business sustainability. Journal of Business Venturing, 18(5), 639-666.

Ouchi, W. 1982). Teoría Z. Barcelona: Orbis.

Pascale, R. and Athos, A. (1983). El secreto de la técnica empresarial japonesa. Barcelona: Grijalbo.

Pearson, A., Carr, J. and Shaw, J. (2008). Toward a theory of familiness: A social capital perspective. Entrepreneurship and Practice, 32(6), 949-969.

Peters, T.J. and Waterman, R.H. (1982). In Search of Excellence. New York: Harper \& Row, Publishers.

Pümpin, C. et García Echevarría, S. (1988). Cultura Empresarial. Madrid: Ed. Díaz de Santos.

Sciascia, S. and Mazzola, P. (2008). Family involvement in ownership and management: exploring nonlinear effects on performance. Family Business Review, 21(4), 331-345.
Sharma, P., Chrisman, J.J., et Chua, J.H. (1997). Strategic management of family business: Past research and future challenges. Family Business Review, 10(1), 135 .

Sharma, P. (2004). An Overview of the Field of Family Business Studies: Current Status and Directions for the Future. Family Business Review, 17(1), 1-35.

Schein, E. (1998). Cultura organizacional y liderazgo. Una visión dinámica. Barcelona: Plaza y Janés.

Svetlik, I. (2000). Some conceptual and operational considerations on the Social Quality of Europe. European Journal of Social Quality, 1, 1/2.

Thevenet, M. (1992). Auditoría de la cultura empresarial. Madrid: Díaz de Santos.

Ward, J.L. (1987). Keeping the family business healthy. How to plan for continuing growth, profitability and family leadership. San Francisco: Jossey-Bass Publishers.

Zahra, S.A., Hayton, J.C. and Salvato, C. (2004). Entrepreneurship in Family vs. Non-Family Firms: A Resource-Based Analysis of the Effect of Organizational Culture. Entrepreneurship: Theory \& Practice, 28, 363381. 